\title{
Development Tourism Village Strategy Of Samiran As A Creative Tourism Model In Central Java
}

\author{
Nina Mistriani ${ }^{1}$, Rudi Prasetyo $\operatorname{Ardi}^{2}$ and Haniek Listyorini ${ }^{3}$ \\ ${ }^{1,2,3}$ STIEPARI Semarang, Indonesia
}

Email: ${ }^{1}$ ninamistriani.stiepari@gmail.com, ${ }^{2}$ rudiprasetyo.undip@gmail.com and ${ }^{3}$ hanilistyorini@yahoo.com

\begin{abstract}
The development of tourism potential in Tourism Village Samiran Boyolali Central Java can be classified as advanced, especially after getting the award as the third best tourist village in the national tourism village appreciation event in 2013 implemented by Menparekraf. This research explores tourism village's creative tourism concept about the strategies undertaken by the community by taking into account the socio-cultural aspects by observing harmonization and connectivity directly with cultural history, as well as living through learning and experience.

This study uses case study research and field research, through field observation activities, as well as interviews of pokdarwis managers, village tour managers Samiran, local communities and tourists. The development strategy conducted by Samiran tourism village towards the concept of creative tourism where local people and tourists are involved in community activities in cultural tourism attractions. This provides an ethical and aesthetic understanding of tourists to appreciate and respect different cultures. The findings of this research is the creative tourism Samiran tourist village is very unique and has a strategic position in Boyolali that can provide added value in the dimensions of tourists and the community on the economic, socio-cultural and environmental aspects.
\end{abstract}

Keywords-Development Strategy, Tourist Village, Creative Tourism Model

\section{INTRODUCTION}

Creative Tourism provides an opportunity for tourists to develop their creative potential. Samiran Selo Tourism Village which teletak in Selo Sub-district, Boyolali Regency, Central Java is one of the tourist village that has the potential of nature and the environment and traditional life of local people who have its own charm.

Selo tourist village, located in District Selo, Boyolali District, Central Java. Its strategic location at the intersection of the route between Solo-Selo-Borobudur (SSB) becomes a tourist attraction opportunity with the best management ecosystem. The nature and environment as well as the traditional life of the local people make Selo has its own fascinating attraction, especially in Samiran Boyolali village. The village is located at an altitude of 1600 to 1800 from sea level, so it has a cool and cool atmosphere. The development of tourism is managed quite well, marked with several awards ever achieved, one of them is the best third winner in the national tourist village appreciation event in 2013 implemented by Menparekraf. Most of the people's livelihoods are in agriculture, plantation and livestock. Agricultural land, as well as its territory in the mountainous areas have fertile soil conditions are an abundant advantage for the local community.

Cultural tourism continues to flourish and is only seen as a meaning for diversity. The great cultural tourism process and the resulting domino effect on many fronts, of course, provides disposable income ("foreigners" activities have had an impact on the fulfillment of their needs (accommodation, amenitas, transportation, other facilities and services), including willingness If the previous ceremonies / rituals and craft products are only used for their own circles with special meanings and functions, then the presence of tourists has added another value to the products and cultural attractions (Nurdiyansah, 2014). 
Strategy Village development of cultural tourism tour is through creative tourism. In creative tourism, the government, the private sector, and the local community will prioritize networking with local communities. Tourists and local people are faced with direct involvement in cultural attractions.

\section{A. Research Problems}

With the development of rural-based tourism in Indonesia, especially in Central Java, it identifies the problems that occur namely the importance of a concept of tourism development that provides benefits to societies that pay attention to aspects of social culture has a harmonization and connectivity directly with history, culture and way of life through learning and experience.

Tourists involved in community activities such as planting rice, harvesting farmers, squeezing cow's milk, doing gardening activities and others. With these activities provide an understanding of the ethics and aesthetics of tourists to appreciate and respect different cultures. Creative Tourism becomes the solution in the concept of tourism development strategy.

The formulation of the problem to be proposed "The development strategy of Samiran resort village to the concept of creative tourism?"

\section{B. Research Objectives}

The main purpose of research in research writing is (1) Identify how the development strategy of Samiran tourist village to the concept of creative tourism. (2) Knowing the impact of tourism development of Samiran tourism village through the concept of creative tourism.

\section{LITERATURE REVIEW}

\section{A. Tourism}

Tourism is the process of traveling a person from his residence to a tourist destination with the intention of not to earn a living in more than 24 hours, but less than 1 year (Marpaung, 2016). Yoeti (1994) states, tourism is a consciously human activity that gets services interchangeably among the people within a country itself or abroad, including the provision of people from other regions to while looking for satisfaction that is diverse and different from what he experienced, where he got a permanent job.

The definition of tourism from the spatial dimension in Indonesia is defined as a tourism activity, as contained in the Tourism Act No.10 of 2009 Article 1, ie travel activities by a person or group of persons visiting a particular place for recreational purposes, personal development, or study the uniqueness of the tourist attraction visited in the interim period.

\section{B. Tourist Profile}

Tourist profiles are the specific characteristics of different types of travelers, closely related to their habits, interests, and travel needs. Understanding tourist profiles is important, as it is useful to provide for their travel needs and develop effective promotional programs. (Happy Marpaung, 2016)

This tourist profile is very important and we need to know to find out what exactly the places visited. In addition, knowing and knowing the world of tourism is useful for all people and stakeholders in the field of tourism, especially those dealing directly with tourists (guests) in order to provide excellent service to them, so they have a good impression and feel given beautiful memories in accordance with what he wants. This can also provide benefits for many who enter the world of tourism.

\section{Tourism Village}

The concept of a tourist village (Agus, 2006) is a rural village that offers a whole atmosphere that reflects the authenticity of the countryside, both in terms of social culture, customs, daily life, traditional architecture, village spatial structure, and has the potential to develop various components tourism, and other tourist needs. As for being a tourist destination, in order to attract to be visited by tourists, must have 3 conditions, namely: 
1. This area must have a "something to see", meaning that there must be tourist attraction and tourist attraction different from that of other regions, the area must have special attraction.

2. In the area should be available "something to do", meaning that in the area besides many that can be seen, must also be provided recreation facilities that can make tourists feel at home longer stay in that place.

3. In the area there should be "something to buy", meaning that there must be facilities in place to shop, especially souvenirs craft the local community as a keepsake, besides it is also necessary to provide money exchange asig and telecommunications.

The elements of the tourist village are:

1. Have the potential of tourism, art, and culture typical of the local area.

2. The location of the village shall be within the scope of the tourism development area or at least within the corridor and route of the tour package already sold.

3. Preferably available managers, coaches and actors of tourism, arts and culture are available.

4. Accessibility and infrastructure support village tourism programs

5. Guarantees security, order, and cleanliness.

\section{Creative Tourism}

UNESCO defines creative tourism as tourism that is related to community development for sustainable way of life. Creative Tourism is a solution to the sustainability of sustainable tourism that takes into account socio-cultural concepts that have harmonization and connectivity directly be it culture, history, and way of life through learning and experience. Creative Tourism provides a balanced participation between the two parties (the community participates in tourism and tourists in community life). Creative Tourism needs to be done tour operator with special attention and approach to society. (Nurdiyansyah: 2014)

\section{E. Tourism Impact}

Tourism development can bring benefits to local communities and other parties in the areas where tourism is growing. Therefore, it

is necessary to implement the strategy of tourism development that can give impact to the society. The impact of tourism (Sammeng, 2000) is:

1. Economics

The positive impact achieved from the development of tourism is the creation of jobs. The community is willing to build tourism, because of the absorption of workers from all competence levels, from unskilled to skilled, even to executive level workers. In this regard in the UK, for example, by realizing the potential for employment from tourism, the Government has set out to develop tourism in areas of high unemployment, many governments are trying to attract investors to build tourism facilities in their countries.

2. Culture

Motivation travels diverse, but for leisure travel it is generally driven by curiosity. This curiosity has encouraged travelers to explore the world to gain new experiences and knowledge. The new experience and knowledge is gained, as it meets with other people / peoples, visits other places, witnesses the cultural manifestation of other peoples / nations. Therefore curiosity (curiosity) is the primary driver for travelers travel that is relaxed (pleasure travel).

3. Environment

Tourists travel, because they are attracted to an object and a tourist attraction. One object or tourist attraction that is strong enough to attract tourists is a beautiful or unique environment. The beautiful surroundings are usually landscapes of the beach, rural with stretched rice fields, marine parks, valleys, mountains, lakes, streams, and wind rushes in the mountains. 


\section{METHODS}

\section{A. Data}

Data is a record of the facts of the observed phenomena / circumstances. The author in taking data using primary and secondary data. Techniques of data collection by survey method through field observation activities, as well as interviews to pokdarwis manager, village tour manager Samilan, local community, and tourists.

\section{B. Method}

This research uses case study and field research methods, that is research that aims to know or study intensively a natural / social phenomenon to find the interrelationship between various phenomena that accompany it. This study will investigate, among others, the background, current state, and social interaction between individuals, groups, communities, and institutions. (Wardiyanta, 2006).

\section{Tables and Figures}

Creative Tourism (Nurdiyansyah: 2014)

1. Community empowerment

2.The learning and experience of travelers

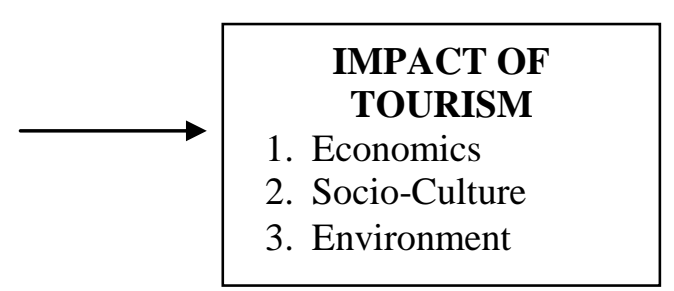

FIG I. RESEARCH FRAMEWORK

\section{RESULTS AND DISCUSSION}

\section{A. The Concept of Creative Tourism}

The Indonesian state is rich in culture, needs to care for culture through conservation efforts and contribution to the welfare of the local people. Economic utilization and long-term conservation needs to be assessed and evaluated on an equal basis. Creative Tourism can be the answer when well planned and sustainable in the long term. For many countries, Indonesian culture has the power that can provide many benefits to the level of income and development. The promotion of culture through creative tourism is a unique form of identity and capital for business and better life for all.

Samiran Boyolali village of Central Java has a creative tourism concept with partnerships with local communities built with fair and equal. This means that the people involved in tourism business and profit sharing contribute to the improvement of people's welfare and support for society to keep the tradition. With the opportunity to participate, people have long-term economic, socio-cultural and environmental uses.

One of the features of the development of culture tourism is through creative tourism. In creative tourism, tour operators (both government, private, and community itself) will prioritize networking with local communities. Tourists and local people are faced with direct involvement in cultural attractions. (Nurdiyansyah: 2014)

\section{B. Community empowerment concept of creative tourism}

Efforts are made to develop the concept of creative tourism Samiran tourist village are:

1. The community realizes the importance of tourism in Samiran Village as a village development capital.

2. The government helps the community in providing basic foreign language training in receiving guests

3. Community involved become local guide.

4. Schedule of Samiran tour visit visits is arranged in advance and coordinated with local community and guide / travel agent. 
5. The community is involved as a welcome guest by displaying local attractions mask ireng, karawitan etc.

6. Farms and plantations become tourist attractions, picking vegetables, milking, mangrove tourism, etc.

7. The community prepares menus for tourists according to the characteristics of tourists.

8. People cultivate agricultural products and plantations to be processed by the tourism industry in the form of products.

9. Organizing dance extracurricular to schools for school children to get to know the local culture, and be involved in welcoming guests

\section{Learning and experience of tourists the concept of creative tourism}

The concept of creative tourism in the village of Samiran can provide learning and experience to tourists, so that tourists can understand and respect different cultures. Society and tourists involved in community life, including:

1. The people are aware of the charm of the main part of tourism, so that the public keeps security, order, cleanliness, cool, beautiful, friendly, and memorable. Tourists feel comfortable in Samiran tourist village, due to the charm factor has been implemented, the example of tourists with friendly and easy to communicate with local and foreign communities.

2. Visit to agricultural home industry guided by local guide. The agricultural produce is processed into vegetable sticks, vegetable chips. Tourists can see the process of making it and can even be involved in learning how to make the process from start to finish.

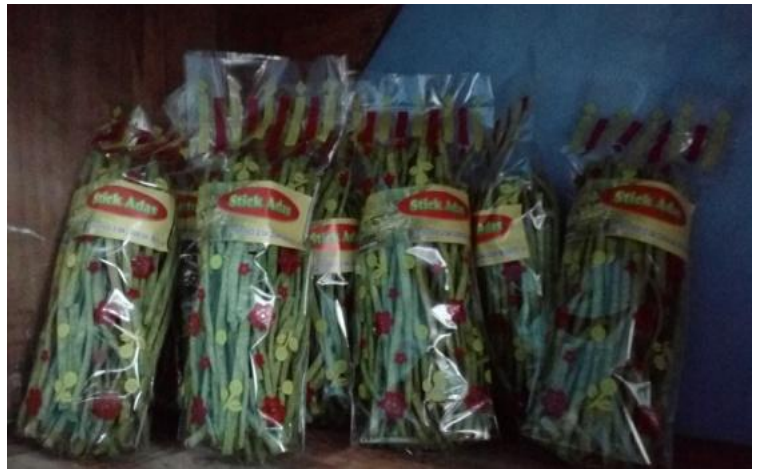

Source: author

FIG II. RESULTS OF VEGETABLE PRODUCTS (STICK OF FENNEL)

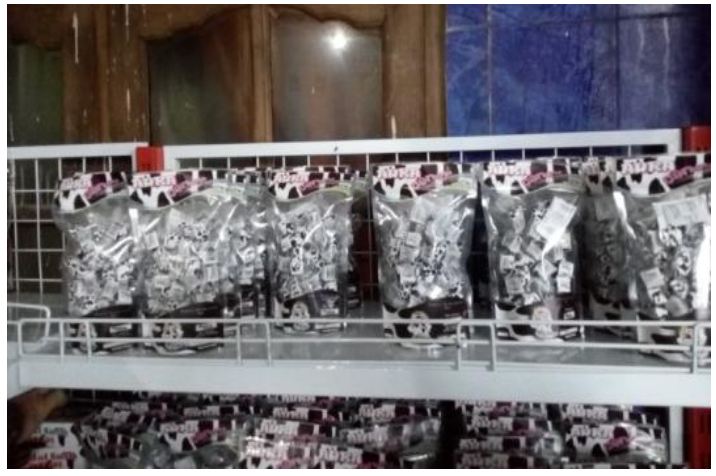

Source: author

FIG III. RESULTS OF COW PRODUCTS

(MILK CANDY)

3. Tourist attraction for tourists who involve the local community, both children and adults presented by the tourist village of Samiran. This attraction is a typical dance of Samiran village. Once the dance attraction is over, the tourists get involved in learning the local culture, either by learning to dance the dance, or introducing the dance through its history. This is an attention and interesting experience for tourists.

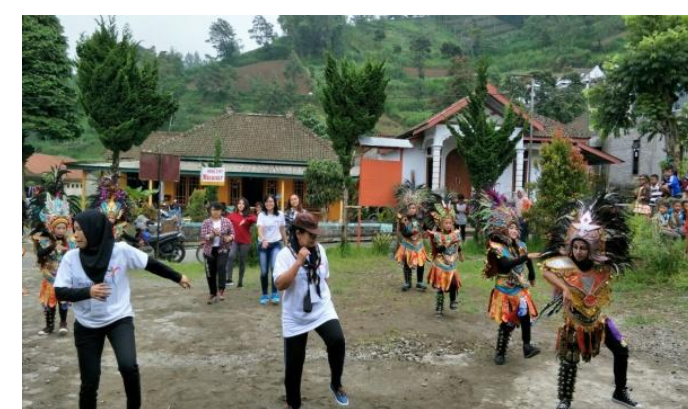

Source: author

FIG IV. DANCE TYPICAL VILLAGE TOUR SAMIRAN TOURISTS DANCE WITH THE COMMUNITY

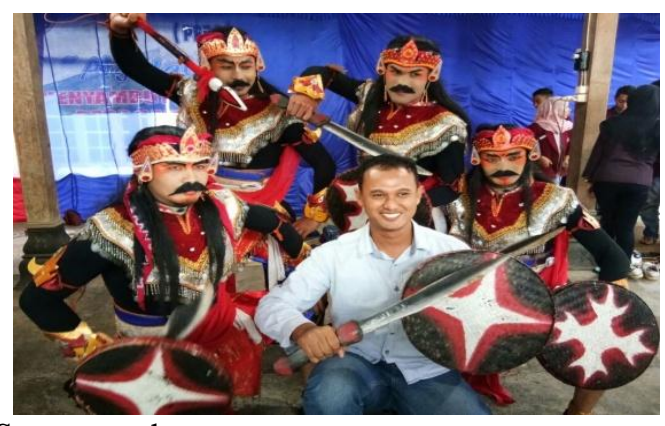

Source: author

FIG V. DANCE TYPICAL VILLAGE TOUR SAMIRAN PHOTOS WITH DANCERS COMPLETED DANCE ATTRACTIONS 
4. Package visits in the field of agriculture include tourists picking vegetables with farm owners, carrying out the process of mangroves from scratch to mangrove, see and learn processed processed agricultural products made products, examples of vegetable sticks, vegetable chips, etc. In addition there is a package of livestock visits, including tourists milking with the owner of the farm, see the process of cow dung into biogas, see and learn processed processed products made by the product, such as milk candy, milk sticks etc .. Experience and learning is done between the community and the tourists directly involved in the location becomes a learning process and an interesting experience in the field of agriculture, farming.

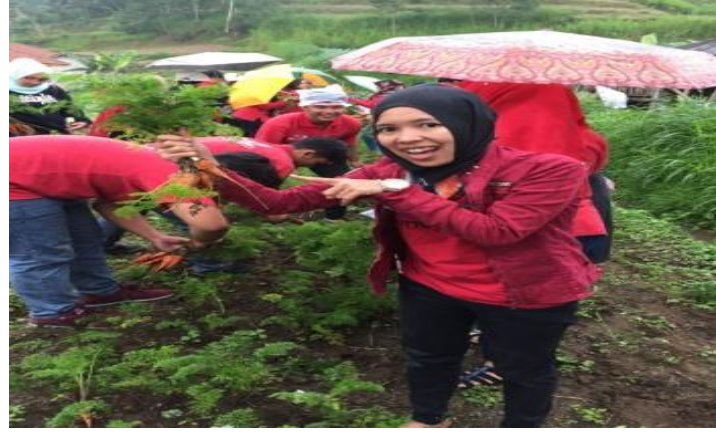

Source: author

FIG VI. PICKING VEGETABLES

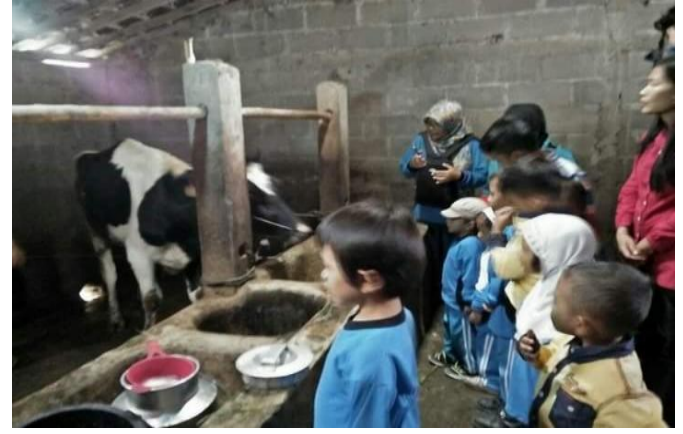

Source: Pokdarwis Samiran tourist village FIG VII. SEEING THE SQUATTING PROCESS OF MILK

\section{Impact of tourism}

\section{Economics}

a) Expansion of employment opportunities

The expansion of tourism employment opportunities is created widely in Samiran tourism village, as seen from the opportunity of natural resources and human resources managed to tourism. Many people are involved in becoming local guides, home industry managers of processed agricultural products, and farms, homestay managers, etc.

b) Economic income

The income of the community increased significantly from the sales of tour packages. The main staple work as farmers, livestock is still getting other side income from tourism. Example of the owner of agricultural land can be income from agricultural land directly leased to tourists doing tourism activities, etc. vegetable picking. Neither in the fields of plantation and farming.

\section{Socio-Culture}

The influence of the existence of tourist villages through tourism undergoes social and cultural changes. This can be seen from people who initially embarrassed to meet with tourists, even just can see from the back door of the residents' house, if there are tourists visiting the tourist village of Samiran. However, the community is now skilled in communicating with both local and foreign tourists. How to dress, and managers homestay homes, already follow the standard of tourism is a healthy home.

\section{Environment}

The management of cow dung waste that was originally disposed of in the drainage channel in front of the community house, with the tourism village through tourism has a positive impact on the environment. Some people who have cattle as livestock starting in 2011 made cow dung waste processing into biogas which is assisted by the government.

In tourism activities, biogas is used for tourist attraction activities to see directly how to make biogas and utilization. Tourists will pay a visit to the people who have cattle farms whose waste has been used as biogas. Utilization of biogas in the community to be used as fertilizer and fuel. 


\section{CONCLUSIONS}

Based on the research that has been done to the development strategy of Samiran tourist village as a creative tourism model in Central Java can be concluded:

1. Samiran Tourism Village has potential natural and cultural potential in accordance with the concept of creative tourism

2. Tourism Village in Indonesia which has a lot of potential can see from the concept developed in the tourist village of Samiran. The focus of development of local communities and tourists involved in community activities in cultural tourism attractions. Both are important to provide an ethical and aesthetic understanding of tourists to appreciate and respect different cultures.

3. Impact of tourism development strategy of the concept of creative tourism such as affecting the economy, social culture and the local environment.

4. Learning and experience of tourists become an important point to increase tourist visits, it is necessary to create the concept of creative tourism by creating creative tour packages.

5. Government can cooperate with tourism village managers to design tourism with creative tourism model development strategy.

\section{RECOMMENDATION}

This research is supported by various parties directly involved in the field. Acknowledgments of the writer to the head of the village tour manager Samiran Ibu Dayang, pokdawris, the local community, the respondents in the field and some who are not directly involved who have helped this research. The hope of the authors of this study can be used as a literature review of further research and useful for readers.

\section{REFERENCES}

Isnaini., Wahyu Nur, Muktiali., Mohammad, (2015) "Pengaruh Keberadaan Desa Wisata Samiran Terhadap Perubahan Lahan, Ekonomi, Sosial, Dan Lingkungan”, Jurnal Teknik PWK (3), Volume 4.

Marpaung., Happy, (2016). "Pengetahuan Kepariwisataan," CV Arfino Raya, Bandung, 11-36.

Nurdiyansyah, (2014). "Peluang dan Tantangan Pariwisata Indonesia," Alfabeta, Bandung, 8-12.

Putra., Agus Muriawan. (2006). "Konsep Desa Wisata," Jurnal manajemen pariwisata (1), Juni volume 5,71 .

Putra., Agus Muriawan. (2006). “Konsep Desa Wisata," Jurnal manajemen pariwisata (1), Juni volume 5,71 .

Sammeng., Andi Mappi, (2000). "Cakrawala Pariwisata," Rafli Lindaryadi, Jakarta, 176-210.

Setyawan., Arif B, Purnomo., Budi, Mulyadi., C Sugeng, (2015). "Upaya Pengembangan Kota Surakarta Menuju Kota Wisata Kreatif,” Jurnal pariwisata Indonesia (1), Volume 11.

"Undang-undang Kepariwisataan", (2009). No.10, pasal 1.

Wardiyanta, (2006). "Metode Penelitian Pariwisata," Andi Yogyakarta, Yogyakarta, 27-36.

Yoeti., Oka A, (1996). "Pengantar Ilmu Pariwisata," Angkasa Bandung, Bandung, Jawa Barat, 116. 